\title{
Virtue, Vice, and Virtual Worlds: \\ A Theological Perspective on Moral Formation
}

\author{
Jacob Shatzer \\ jwshatzer@gmail.com
}

\section{Introduction}

The virtual is very accessible. What was once the realm of those with access to expensive technological equipment is now available to anyone with a computer and a high-speed Internet connection. The computer serves as a terminal to other worlds, worlds filled with wizards, warriors, and talking animals. Some even prognosticate a mass exodus to virtual worlds, with an increasing number of people spending more time there and demanding the real world to change if it wants them back. ${ }^{1}$ As more people move significant portions of their lives into virtual worlds, the way they are shaped there will influence their real-world moral formation, their growth as holistic human beings, and their ability to live within authentic community. ${ }^{2}$

In order to understand what is at stake, this increasingly popular "destination" requires careful evaluation. The following seeks to highlight what is at stake from a Christian theological perspective. First, I will describe this particular perspective along with key theological themes. Second, I will briefly describe virtual worlds with one particular example, Second Life. Finally, I will address pertinent issues of moral formation, bringing the theological perspective to bear on virtual worlds and the particular challenges they can pose to moral formation. While virtual worlds should not be demonized or avoided altogether, Christians must be aware of the unique

\footnotetext{
${ }^{1}$ See Edward Castronova, Exodus to the Virtual World: How Online Fun Is Changing Reality (New York: Palgrave Macmillan, 2007).

${ }^{2}$ Sherry Turkle has done great work on the subjective side of the human-computer relationship. See especially Sherry Turkle, Alone Together: Why We Expect More from Technology and Less from Each Other (New York: Basic Books, 2011). Also, Nicholas Carr has recently done excellent work concerning the way our time online can influence and change our brains. See Nicholas Carr, The Shallows: What the Internet Is Doing to Our Brains (New York: Norton, 2010).
} 
challenges they can pose to the development of human character and community as defined theologically.

\section{Theological Perspective and Key Themes}

Before describing the technological issues to be explored, it will be helpful to set out a basic framework for some theological themes that will prove useful in the analysis. Christian theology seeks to speak humbly about God as he has revealed himself through the Scriptures and through his church. It especially revolves around Jesus' Greatest Commandment: love God and love the neighbor. This is such a simple command; yet it is so difficult to apply and to carry out, especially with advanced technology in view. What does it mean to love God and love the neighbor in virtual worlds? The following theological themes are drawn from the work of James K. A. Smith, a Pentecostal theologian, and A. J. Conyers, a Baptist theologian. Smith develops an anthropology of humans as lovers, with the proper object of love being God. Conyers works with themes related to community and what it means to love God and neighbor in light of the challenges of modern society. Though each speaks from his particular faith tradition, the themes that are detailed here are broadly Christian and can be appropriated by a variety of faith traditions.

\section{Humans as Lovers}

In his recent book Desiring the Kingdom, Smith insists on the importance of philosophical anthropology for thinking about education and formation. He lays out two anthropologies that he finds deficient. First, a dominant model that is as old as Plato and rebirthed by Descartes views the human person as a thinker. ${ }^{3}$ Protestant Christianity in particular

\footnotetext{
${ }^{3}$ James K. A. Smith, Desiring the Kingdom: Worship, Worldview, and Cultural Formation (Grand Rapids: Baker Academic, 2009), 41-43. 
has absorbed this view of the human, resulting in a "talking-head version of Christianity that is fixated on doctrines and ideas." ${ }^{4}$ Second, some argue that thinking operates on the basis of faith, so the human should be viewed primarily as a believer. ${ }^{5}$ The idea is that, before we are thinkers, we are believers. While acknowledging the strengths of both positions, Smith ultimately sees both as emphasizing something that is less than primary, and he proposes a different anthropology.

Understanding the human person as lover can be traced at least as far back as Augustine and takes into account the complexity of human existence. ${ }^{6}$ Smith sees four key elements in this model: humans are intentional creatures whose fundamental way of intending is love or desire; this love (which is unconscious and non-cognitive) is always aimed at some particular version of the good life; sets of habits and dispositions prime us to be oriented and to act in certain ways; and affective, bodily means, such as bodily practices, routines, and rituals, grab hold of the heart through the imagination and form the person. ${ }^{7}$ What the person loves is what the person worships.

This model shifts the focus from the cognitive to the affective aspects of identity formation. Love takes practice, and that practice occurs in ways that many people do not realize. Smith mentions "thin" habits (mundane activities, like brushing teeth, which seemingly do not touch our love or desire) and "thick" habits (meaning-full activities that play a significant role in shaping our identity and our loves). ${ }^{8}$ However, there are no neutral practices, whether thick or thin. For instance, thin practices can serve thick ends, such as the daily habit of exercising, which can serve the end of wanting to see one's children grow up and spend many years of friendship

\footnotetext{
${ }^{4}$ Ibid., 42.

${ }^{5}$ Ibid., 43-46.

${ }^{6}$ Ibid., 46-63.

${ }^{7}$ Ibid., 62-63.

${ }^{8}$ Ibid., 82 .
} 
with one's spouse. Thick formative practices are "meaning-laden, identity-forming practices that subtly shape us precisely because they grab hold of our love- they are automating our desire and action without our conscious recognition." 9

"Liturgy" serves as the lens for analyzing practices. Smith defines liturgies as "ritual practices that function as pedagogies of ultimate desire." ${ }^{\prime 10}$ This can obviously apply to religious practices, but Smith extends the analysis to "secular liturgies" in order to get at the way humans are being shaped in fundamental ways by cultural institutions that often pass without much careful thought. While some may initially hesitate to apply liturgy to seemingly secular practices, the use is appropriate and helpful because it focuses not on the formation of the liturgies themselves but the way the ritual practices shape human desire.

Smith focuses on three examples. The mall (consumerism) reflects what matters and shapes what matters. The military-entertainment complex (nationalism) seeks to orient allegiance solely to the state. The university, also, is not primarily about information but about shaping imagination and desire so that students will pursue a particular vision of the good life. ${ }^{11}$ Secular institutions project a version of what is broken in the human condition, what true flourishing looks like (what should be desired), and how to act in order to achieve success. Simple practices are not innocent, for they form the heart.

This philosophical anthropology of the human as lover and the understanding of "secular liturgies" raise the stakes for understanding virtual worlds from a Christian theological perspective. Smith's analysis will help focus our attention not only on what people do within these worlds, but how these worlds can serve as forming liturgies.

\footnotetext{
${ }^{9}$ Ibid., 83.

${ }^{10}$ Ibid., 87.

${ }^{11}$ Ibid., 93-121. 


\section{Hearing God's Call}

In The Listening Heart, Conyers seeks to address the crisis of modern culture from a Christian perspective. ${ }^{12}$ In particular, he sees societies that have become untethered from any sense of the transcendent and any sense of calling; instead, they focus on the modern celebration of unfettered human will. While this book does not address virtual worlds at all, the themes that Conyers develops around vocation, attention, and community provide a helpful perspective from which to assess virtual "communities" and the formation that occurs within a virtual world.

Conyers laments that modern society has lost a sense of vocation, a sense that was vital for the formation of strong societies in pre-modern times. "The term 'vocation' stands for all of those experiences and insights that our lives are guided by Another, that we are responding not to inert nature that bends to our will, but to another Will, with whom we might live in covenant relationship, and to Whom we will be ultimately accountable."13 This sentiment of divine call "gives to the society in which it is embedded a certain character that we would find to be distinctly non-modern."

Four points highlight this distinction. First, "the idea of a call implies an agent outside of the one who is subject to the call." ${ }^{\prime 15}$ People are given freedom to respond to a summons; freedom is not an inner-directed impulse but the use of the will to respond. There is a difference between a society that incorporates some sense of vocation and one that explains behavior in other ways. Second, "the summons is often against the will of the one who is called into service." $" 16$ This stands in stark contrast to post-Enlightenment thought, which often emphasizes

\footnotetext{
${ }^{12}$ Conyers has also done significant work on the Christian view of history, specifically in relation to the work of Jurgen Moltmann.

${ }_{13}^{13}$ A. J. Conyers, The Listening Heart: Vocation and the Crisis of Modern Culture (Dallas: Spence, 2006), 112.

${ }^{14}$ Ibid., 13.

${ }^{15}$ Ibid.

${ }^{16}$ Ibid.
} 
reason as a replacement for the idea of vocation. ${ }^{17}$ Third, "the calling involves in almost every case hardships that must be overcome in order to answer the summons." ${ }^{18}$ Jeremiah, Ezekiel, Muhammad, Mani, Socrates, Jesus, and Paul all confronted the threat of death by their communities. Fourth, "from the point of view of answering to the summons, the greatest danger appears ... in the possibility of being diverted or distracted from the goal." ${ }^{\prime 19}$ Conyers notes that "These distinctive features of vocation found in traditional societies help us to mark off what is now different in our own modern and Western culture. While the sentiment is still there in form and in vocabulary, its striking force and its assault upon the ego are all but dissolved." ${ }^{20}$

One theme connected to this loss of vocation is the grasping after both power and control. Knowledge is sought for the purpose of mastery and control rather than participation in community. ${ }^{21}$ In fact, "Power has become the centerpiece of a new kind of harmony, one based no longer on the 'right relation of things' in a world that both begins and ends in mystery, but it is a harmony that comes from control." ${ }^{, 2}$ Control diminishes relationship; the will of one alone is expressed, and conversation and communion are lost. ${ }^{23}$ A loss of vocation that emphasizes the individual will and promotes the desire to control castrates the propagation of genuine community.

Attention is the appropriate response to vocation. This "means the overthrowing of "vain imaginations,' the disposal of a self-centered view of existence." ${ }^{, 24}$ It is important to Christian thought and practice, because prayer consists in attention. "The purpose and end of attention is

\footnotetext{
${ }^{17}$ So one makes reasoned choices rather than depending on guidance from another. Ibid., 14.

${ }^{18}$ Ibid., 15.

${ }^{19}$ Ibid.

${ }^{20}$ Ibid.

${ }^{21}$ Ibid., $57-60$.

${ }^{22}$ Ibid., 79.

${ }^{23}$ Ibid., 92.

${ }^{24}$ Ibid., 121.

${ }^{25}$ Ibid., 119.
} 
a transformation in which reality awakens within us, pushing aside the unreal and selfish dreams which had kept us subdued in unwakefulness. ${ }^{26}$ This stance is contrary to today’s world, because "Society prefers the narcotic of refusing to face painful situations believing that, by refusing reality, it is affirming life." 27 "If vocation is the opposite of a life simply chosen, from among differing alternatives, or among numberless innocuous choices, whether we call these 'lifestyles,' or 'alternate realities,' then it involves facing and accepting both the limits and the painfulness of that for which we are chosen." 28

The opposite of attention is distraction. Conyers argues, "We are distracted. To be modern is to exist increasingly in a state of distraction." ${ }^{, 29}$ We justify this life of distraction, which tries to pull apart what belongs together in the eyes of faith. The modern human is distracted from knowing in order to participate and instead seeks to know in order to master, which brings separation. The problem is one of our affections; we have failed to love properly. ${ }^{30}$ The modern era provides intense opportunities for distraction.

For Conyers, all of these issues come together in the concept of community, which he worries is in danger in the modern setting. "Here is a literal picture of the community that is in any real sense men and women communing together about life: nourished and informed by virtue of their rootedness, oriented toward their destiny, and open in love toward one another- this is the succinct meaning of community, the aim of which is to provide space and give nourishment to the human spirit." 31 True community is promoted when the members refuse to seek power and control and instead attempt to hear and follow God, living a life that is faithful to God and open

\footnotetext{
${ }^{26}$ Ibid., 121.

${ }^{27}$ Ibid., 126.

${ }^{28}$ Ibid., 127.

${ }^{29}$ Ibid., 55.

${ }^{30}$ Ibid. Conyers's analysis dovetails nicely with Smith here.

${ }^{31}$ Ibid., 113. 
to one another. Cultures that promote individualism and control contribute to the dissolution of community; they "imitate the form of community but deny its substance." 32

Thus Smith and Conyers help form a theological perspective from which to attempt to understand virtual reality and its ethical implications. Humans are essentially lovers, and we learn love by practice. The themes of vocation and attention serve to drive true community flourishing. Thus "secular liturgies" can be analyzed in order to understand whether or not they shape human affections for this sort of community and human flourishing. Virtual worlds serve as an example of one such "liturgy," and these themes from Conyers will prove fruitful for analysis and evaluation after we have described what virtual worlds are.

\section{Overview and Example of Virtual Reality}

Virtual reality is a rapidly developing field, so any reflection will inevitably seem a bit outdated. However, utilizing key research and description of the field, it is possible to outline some basic historical understanding and description of key features in order to move toward theological reflection and engagement. The following provides a general overview before moving to describe Second Life as a specific example of the type of virtual world in view.

\section{Overview}

In this investigation, the following definitions will be important. Anthropologist Tom Boellstorff defines a virtual world as a place of human culture realized by computer programs through the Internet. ${ }^{33}$ However, "Forming a terminology thus presents challenges, particularly because virtual worlds change so swiftly and conceptual imprecision is far from unknown." ${ }^{34}$ It

\footnotetext{
${ }^{32}$ Ibid., 94.

${ }^{33}$ Tom Boellstorff, Coming of Age in Second Life: An Anthropologist Explores the Virtually Human (Princeton: Princeton University Press, 2008), 17.

${ }^{34}$ Ibid. 
is necessary to establish what characteristics are non-negotiable while allowing room for development as the worlds themselves change with technological innovation.

Here the work of Ralph Schroeder is particularly helpful. ${ }^{35}$ He provides a clear definition of "virtual environments" and "virtual reality" technology as "a computer-generated display that allows or compels the user (or users) to have a sense of being present in an environment other than the one they are actually in, and to interact with that environment." A "virtual world" is a "persistent virtual environment in which people experience others as being there with them-and where they can interact with them." These definitions highlight both the immersive nature of these environments as well as the persistent quality of "virtual worlds." They do not cease to exist when a user logs off; people continue to inhabit them, events happen, and things can change. Schroeder succeeds in incorporating the technological needs for virtual reality while distinguishing virtual environments and virtual worlds. Virtual worlds, then, are persistent virtual environments, which are computer-generated, alternative, interactive spaces that rely on the technology of virtual reality.

It is important to realize the "virtual" in these senses is not the opposite of "real." A virtual world is a type of virtual environment, one that is especially marked by consistent existence. The key distinction of a virtual world is that it endures through time; it still exists even when one particular user leaves. Virtual environments, on the other hand, do not necessarily have this characteristic (for example, some sort of testing environment that is used only at particular times for specific purposes). The focus of this theological evaluation is the effect of virtual worlds on moral formation.

\footnotetext{
${ }^{35}$ Ralph Schroeder, "Defining Virtual Worlds and Virtual Environments." Journal of Virtual Worlds Research 1, no. 1 (2008). 
Terms "real world" and "real life" will be used to distinguish the realm of life that does not take place within the computer. This is not meant to imply that time spent in virtual worlds is not real or does not have real consequences; I use "real life/world" for ease of communication and distinction, not to enforce some duality between the two. The user remains "real" even while staring into the screen, but the term "real world/life" helps distinguish between life "in the computer" and life outside it, while acknowledging that all of life is real and has real consequences.

Finally, three terms will be used interchangeably for people who dwell in these virtual worlds. "Users," "residents," and "players" are synonyms in this discussion. ${ }^{36}$ While some may argue that these are merely games and thus not worthy of careful reflection, it seems clear that they are growing in importance as an increasing number of people spend a greater amount of time engaging them. ${ }^{37}$

Different types of virtual reality can be defined based upon the level of immersion, which is related to the physical configuration that the user interface provides. There are three classifications: fully immersive, using a head-mounted device; semi-immersive, using large projection screens; and nonimmersive, using a desktop-computer-based system (or a laptop).

\footnotetext{
${ }^{36}$ Some game discussion makes distinctions here. "Users" can be considered too impersonal, so "residents" is used for worlds like Second Life that emphasize sociality and creativity, and "players" is used for rule-oriented worlds.

${ }^{37}$ In his work on virtual communities and worlds, Paul Ford notes three common criticisms about the subject matter. First, some people see the virtual as interesting but with little relevance to daily life. Ford counters that even though people do not spend all of their time in these communities, they are dynamic elements that supply a small but valuable sphere of meaning. Second, some see a lack of depth in the interaction that occurs in these environments. On the contrary, interpersonal interactions in these communities have developed a great level of complexity. Third, some see these communities and worlds as only significant for those on the margins of society. However, the current growth rate of these environments suggests otherwise. These are but three objections to the seriousness of scholarship on virtual worlds, but they serve as an example of arguments that can be made showing that virtual worlds will only become more relevant as more people spend time in them. See Paul J. Ford, "Virtually Impacted: Designers, Spheres of Meaning, and Virtual Communities," in Virtual Morality: Morals, Ethics, and New Media, ed. Mark J. P. Wolf (New York: Peter Lang, 2003), 85-89.
} 
This classification depends entirely on how much the user can perceive the real world while engaged in a virtual world. ${ }^{38}$

The nonimmersive type of virtual reality is of particular interest in this investigation because of its widespread availability and potential to influence a larger proportion of the population than more immersive forms. Another important distinction can be made here. Nonimmersive virtual reality can be divided into the ludic and the paidic. Ludic virtual worlds are "ruled-based games involving direct competition between players," while paidic worlds "emphasize free play and creativity with less emphasis on rule-constrained competition." 39 Paidic virtual worlds are also known as "non-game virtual worlds.",40

The history of virtual worlds can be narrated from two different angles. ${ }^{41}$ On the one hand is development history. As computer technology has advanced, virtual reality has developed as different degrees of immersion and experience become possible. MMOGs (massively multiplayer online games) became popular as technology developed the necessary graphic and online capabilities. First, social virtual worlds (or paidic worlds; see above) emerged as graphics became more developed. ${ }^{42}$ In these worlds, users navigate an avatar (usually a cartoon-like character) through the world mainly with the purpose of interacting with other users.

\footnotetext{
${ }^{38}$ Mario A. Gutiérrez, Frédéric Vexo, and Daniel Thalmann, Stepping into Virtual Reality (London: Springer, 2008), 2.

${ }^{39}$ William Sims Bainbridge, Online Multiplayer Games (Morgan \& Claypool, 2010), 1.

${ }^{40}$ For a helpful description of two such worlds, see Kathryn Stam and Michael Scialdone, "Where Dreams and Dragons Meet: An Ethnographical Analysis of Two Examples of Massive Multiplayer Online Role-Playing Games." Online-Heidelberg Journal of Religions on the Internet 3, no. 1 (2008).

41 "These perspectives can emphasize the role of virtual worlds in a variety of histories: games (digital or otherwise), communication technologies, online communities, non-linear literature, collaborative story telling and/or performance; not to mention a deeper history of creation and interaction with other-worlds that has persisted since the earliest days of homo-sapiens." See Calleja, "Virtual Worlds Today," 16. For recent in-depth accounts of the history of virtual reality, see Phylis Johnson, Second Life, Media, and the Other Society (New York: Peter Lang, 2010), 3-21. Also, see Boellstorff, Coming of Age in Second Life, 32-59.

${ }^{42}$ Some thinkers separate social virtual worlds from MMOGs because they lack the rules and objectives that other games do. However, I choose to keep them together here since they are still very similar and can be distinguished in other ways.
} 
Consalvo points to a game called Habitat as a pioneer in this field, ${ }^{43}$ the first to adopt an openended philosophy. ${ }^{44}$ This is the philosophy followed in popular games such as Second Life.

Second, virtual worlds emerged with more rules and objectives, with more of a traditional "game" feel (ludic worlds; see above). Examples include Ultima Online and Everquest. ${ }^{45}$ Another type of MMOG is the MMORPG (massively multiplayer online role-playing game), such as World of Warcraft, which enjoys the greatest degree of popularity. ${ }^{46}$ In these games users have different types of characters to choose from (priest, elf, human, etc.) that come with different strengths and responsibilities within the game. Thematically, virtual worlds can be traced to role-playing games such as Dungeons and Dragons, which was popular beginning in the 1970 s. ${ }^{47}$ In games like this, the players assumed different roles that had certain responsibilities and abilities. The popularity of such games is sometimes traced to certain genres of literature, with J. R. R. Tolkien's Lord of the Rings trilogy providing a large degree of conceptual inspiration. ${ }^{48}$ As the technology developed, these types of games themselves became online versions, and new games based on similar themes emerged.

On the other hand is user history. The popularity of virtual worlds did not spring forth from nothing. First, video gaming has steadily risen in popularity since the 1970s. In fact, 40 percent of adults are now regular players, and the average player age is $33 .{ }^{49}$ Also, virtual worlds allow creative individuals to construct their own spaces and objects within the world, which

\footnotetext{
${ }^{43}$ Mia Consalvo, "MOOs to MMOs: The Internet and Virtual Worlds," in The Handbook of Internet Studies, ed. Mia Consalvo and Charles Ess (Malden, MA: Blackwell, 2011), 328.

${ }^{44}$ Gordon Calleja, "Virtual Worlds Today: Gaming and Online Sociality." Online-Heidelberg Journal of Religions on the Internet 3, no. 1 (2008): 20.

${ }^{45}$ For more details on these specific games, see Ibid., 27-38.

${ }^{46}$ Eleven million subscribers in 2009. See Phylis Johnson, Second Life, Media, and the Other Society (New York: Peter Lang, 2010), 15.

${ }^{47}$ T. L. Taylor, "Internet and Games," in The Handbook of Internet Studies, ed. Mia Consalvo and Charles Ess (Malden, MA: Blackwell, 2011), 370.

${ }^{48}$ Bainbridge, Online Multiplayer Games, 11.

${ }^{49}$ Dmitri Williams, Nick Yee, and Scott E Caplan, "Who Plays, How Much, and Why? Debunking the Stereotypical Gamer Profile." Journal of Computer-Mediated Communication 13 (2008): 993.
} 
connects to the user-created content feature of popular social networking sites and Web 2.0 in general. $^{50}$

Before moving on to a specific example of a paidic virtual world, one objection must be addressed. Since popular virtual reality, especially paidic virtual worlds, essentially connect people together for the purpose of communication, some might argue that this type of virtual reality is merely an advanced communications device that uses avatars and virtual environments to facilitate conversation. ${ }^{51}$ If this were the case, these worlds would not merit much reflection beyond other communications technologies. However, there is a key distinguishing factor that must be understood from the outset. Paidic virtual worlds are not merely new communicative media, because users not only communicate using this technology but they also share common experiences that shape them as moral agents. As Sherry Turkle has observed in her extensive research on the relationship between humans and computers, "Virtual communities ... allow people to generate experiences, relationships, identities, and living spaces that arise only through interaction with technology., ${ }^{, 52}$ Also, users often invest such a large amount of time in their avatars that they become extremely meaningful. ${ }^{53}$ So, because virtual worlds not only serve as communications media but also as a source for generating experiences, they must be analyzed more carefully. $^{54}$

\footnotetext{
${ }^{50}$ Consalvo, "MOOs to MMOs: The Internet and Virtual Worlds," 329.

${ }^{51}$ For example, Ralph Schroeder views virtual environments as another type of mediated presence and copresence. See Ralph Schroeder, Being There Together: Social Interaction in Virtual Environments (New York: Oxford University Press, 2011).

${ }^{52}$ See Sherry Turkle, Life on the Screen: Identity in the Age of the Internet (New York: Simon \& Schuster, 1995), 12. In another work, she notes, "Involvement with simulated worlds affects relationships with the real one." See Sherry Turkle, The Second Self: Computers and the Human Spirit (New York: Simon and Schuster, 1984$), 82$.

53 "The point is that many game players invest so much time in their characters, often 'sharing' intensely emotional experiences with them, that they can become extremely meaningful." See Bainbridge, Online Multiplayer Games, 55.

${ }^{54}$ Clearly, it could be argued that every form of mediated communication generates experiences that shape people. For instance, using the telephone was a different experience than speaking directly to a person. For virtual worlds, however, the scope and variety of generated experiences is so wide, and the immersion in them is so deep, that they are more formative in the experiences they generate. Also, virtual worlds provide the opportunity for experiences in
} 


\section{Focusing on One Paidic World: Second Life}

Second Life (SL) was launched in 2003. It is "a virtual social network platform that allows its residents to create alternate identities, drawing from real and idealized life," and "possibilities are endless when in avatar form." Account creation is free, so there is no cost to basic exploration of the world. ${ }^{56}$ There are approximately 14 million accounts, and 40,00060,000 users are usually online at any given time. ${ }^{57}$ Users create their own avatar, whose appearance they completely control by choosing from various options and purchasing accessories. They can interact with any avatars that they encounter. As they move through the world using basic computer navigation, they can type or speak to nearby people. If one user wants to remember another and be notified whenever the person is in SL, they can send a friend request. This helps maintain relationships between visits to the world and enables users to find one another. Travel in the world occurs in three ways: walking, flying, and teleporting, which obviously offer differing degrees of speed and interaction with objects in the world.

As a "paidic" virtual world, SL exists mainly for social interaction and creativity. Users can communicate by typing or speaking to nearby avatars, and the game allows users to create objects by shaping virtual materials and putting them together. Users who do not own land can create in the "sandbox," but their objects will be deleted after a short period of time. Owning

\footnotetext{
which communication is a secondary concern, unlike previous forms of communication technology, which were consistently tied to communication.

${ }^{55}$ Johnson, Second Life, xvi-xvii.

${ }^{56}$ For a helpful description of how to sign up for a typical virtual world, see Edward Castronova, Synthetic Worlds: The Business and Culture of Online Games (Chicago: University of Chicago Press, 2005), 29-50. Castronova's description includes a typical payment method, which does not apply in this case. This chapter still gives a good taste for those who have no previous exposure to these worlds.

${ }^{57}$ Johnson, Second Life, xiii-xiv. This is a more conservative number. Another resource puts the number closer to 17 million accounts. See Kimberly Rufer-Bach, The Second Life Grid: The Official Guide to Communication, Collaboration, and Community Engagement, 1st ed. (Indianapolis, Ind.: Wiley, 2009), 7. It is likely closer to 20 million in 2011.
} 
land provides the ability to create and maintain objects, with the quantity being dependent upon the amount of land owned. Such objects can be sold. A thriving in-world economy exists, as users purchase digital items from one another. There is an in-game currency that maintains an exchange rate with US dollars, ${ }^{58}$ and user-to-user transactions average around $\$ 50$ million each month. ${ }^{59}$ Clearly, such a popular game is serving as a "secular liturgy" for millions of people.

Since much of the literature on Second Life was published detailing its popularity and potential, ${ }^{60}$ there has been a backlash of sorts. Many of the accounts are actually inactive, since it is free to set one up. Many high-profile businesses have sought a presence in SL and have not found it to be a financial success. Some blame this on the fact that no one really knows how popular SL actually is. ${ }^{61}$ Another explanation might be that users resent big-name companies intruding on their space. ${ }^{62}$ Others see the problem extending beyond marketing within SL and doubt the viability of this particular virtual world in the future ${ }^{63}$ However, SL still demonstrates measurable growth, and metrics show that many still find it worth their time. As of the end of June 2011, there were just over 2.4 million signups. According to data from late 2010, almost 600,000 users use the site each week. Approximately 34,000 have active "homes" in the world. ${ }^{64}$ There also remains a bustling in-world economy. In fact, in the first quarter of 2010, user-to-user

\footnotetext{
${ }^{58}$ In 2009 , the rate was approximately L $\$ 260$ to L $\$ 270$ to the US dollar.

${ }^{59}$ Johnson, Second Life, 265.

${ }^{60}$ For an example of such optimism, see Jia Dai, "Virtual Worlds, Real Brands: A Critical Interrogation of Commodification in Second Life," in Living Virtually: Researching New Worlds, ed. Don Heider (New York: Peter Lang, 2009). Another example is an article in which the authors speculate that by 2012, 80 percent of Internet users will have some sort of presence in a virtual world like SL. See Paul R. Messinger, Eleni Stroulia, and Kelly Lyons, "A Typology of Virtual Worlds: Historical Overview and Future Directions." Journal of Virtual Worlds Research 1, no. 1 (2008): 2.

${ }^{61}$ Cade Metz, "The Popularity of Virtual Worlds Is Exaggerated," in What Is the Impact of Cyberlife?, ed. Andrea Demott (Farmington Hills, MI: Greenhaven, 2008), 14.

${ }^{62}$ Ibid.

${ }^{63}$ Mitch Wagner, "Second Life CEO Looks to the Future, after Massive Layoffs," http://blogs.computerworld.com/16303/second_life_layoffs.

${ }^{64}$ User data from "Second Life Grid Survey," $\overline{\mathrm{h}} \mathrm{ttp}: / /$ www.gridsurvey.com/.
} 
transactions totaled $\$ 160$ million. ${ }^{65}$ So, while the future of SL no longer reaches the heights and optimism that it did five years ago, it remains a viable virtual world. And, for the purposes of this analysis, it serves as a helpful example of what a virtual world is whether it remains the leading example or not.

All sorts of behavior occur in the world. In the words of one thinker, "Cyberspace creates new classes of imagination and subjective activity. The question of what is 'real' and what is 'fantasy' as well as the question of when such a distinction should matter ... has become newly relevant to the culture at large." ${ }^{66}$ Four types of behavior will be briefly described. The first two tend to be more "negative" in traditional moral description: "griefing" and sexual expression. The second two are more "positive": collaboration and religious expression. The point of the following is not to construct arguments to evaluate normatively the moral status of these particular actions; instead, it is to describe briefly some morally relevant behavior, whether positive or not.

"Griefing" is basically taking pleasure from causing harm to other players. ${ }^{67}$ One SL resident described it as “deliberately doing something that interferes with other users' Second Life experience. ${ }^{, 68}$ This can take various forms. ${ }^{69}$ On the one hand, the creation of offensive objects can be considered griefing (for example, large signs with real-world political slogans, or objects blocking the view from someone's home). On the other, the creation of extremely complicated objects or self-replicating objects can be a form of griefing if it is done to slow down other people's computers or crash the server. While this activity does not do physical harm

\footnotetext{
${ }^{65}$ Don Clark, "Second Life Creator Linden Lab Downsizes, Morphs," Wall Street Journal, http://blogs.wsj.com/digits/2010/06/10/second-life-creator-linden-lab-downsizes-morphs/.

${ }^{66}$ Kimberlyn Leary, "Cyberplaces," in The Inner History of Devices, ed. Sherry Turkle (Cambridge, Mass.: The MIT Press, 2008), 95.

${ }^{67}$ Bainbridge, Online Multiplayer Games, 41.

${ }^{68}$ Boellstorff, Coming of Age in Second Life, 187.

${ }^{69}$ In other virtual worlds that are more combat-oriented, griefing often takes the form of actual violence against lessexperienced players.
} 
to people, the activity can still be considered dangerous because of its negative impact on the agent and the victim. ${ }^{70}$ There are also less-sophisticated forms of griefing: verbal abuse of other users or other inappropriate behavior such as avatars wearing offensive costumes, or nothing at all.

Sexual expression is a graphic part of Second Life. The creators of the world have made a "ratings" system, so different areas of the world allow more explicit activity than others, and users can be suspended or have their accounts deleted for violating these ratings. However, within the proper areas, sexual expression is allowed and enabled by both coding for actions and speech capabilities. Different users have different feelings about what "fidelity" to a real-world spouse means in the context of SL. Some users even marry other avatars while being married to another person in real life, though these ceremonies are usually secular rather than religious. Some argue that this sexual expression is a healthy and normal event driven by deep emotional relationships established online. Philip Rosedale, CEO of Linden Lab, insists that, "A lot of the sex relationships in Second Life are driven more by lengthy, meaningful discussions ... People have sex in Second Life because they have incredibly deep relationships, not just because they want to have sex."71 Other expressions of sexuality have come under more fire in SL. For example, Linden Lab has cracked down on "ageplay," which involves childlike avatars. ${ }^{72}$ Clearly, sexual expression emerges in various forms within SL, and whatever one thinks about where the line for appropriate behavior falls, sex plays an important role in virtual worlds. ${ }^{73}$

\footnotetext{
${ }^{70}$ Noreen Herzfeld, "Bodies Matter: A New Fad and a Fallacy in the Name of Science," in God's Action in Nature's World (Burlington, VT: Ashgate, 2006), 229. For more description of actual instances of griefing in SL, see Peter Ludlow and M. Wallace, The Second Life Herald: The Virtual Tabloid That Witnessed the Dawn of the Metaverse (Cambridge, Mass.: MIT Press, 2007), 89-107.

${ }^{71}$ Mitch Wagner, "Sex Is Integral to Virtual Worlds," in What Is the Impact of Cyberlife?, ed. Andrea Demott (Farmington Hills, MI: Greenhaven, 2008), 49.

72 Ibid., 44-46.

${ }^{73}$ Again, the point here is not to argue for or against sexuality in SL, but to describe it vaguely as part of the horizon of possibilities in this virtual world.
} 
On a more "positive" note, SL and virtual worlds in general contain a strong ethic toward cooperation, kindness, and mutual aid. ${ }^{74}$ This takes many forms in SL. Some users are quick to give away objects to others, especially newer users who have less. Also, residents are typically quick to invite others to social events, even people whom they have not interacted with in the past. Experienced users also offer their knowledge on subjects such as building and other elements of the SL interface that can be difficult to master. Large groups exist solely for the purpose of helping newcomers to the world. The help often extends into "real-life" problems as well, with people sharing problems and offering advice to one another. While the negative activity often gets more publicity, the dominant ethos is one of kindness and mutual aid.

Religious expression is very common on the Internet, ${ }^{75}$ and SL is no exception. ${ }^{76}$ In the following, religious practice in general will be described briefly, including helpful information about ritual in general as well as specifics about different religions and their presence in SL. Then Christian religious experience in particular will be treated.

All of the world's major religions are represented in SL. ${ }^{77}$ An important distinction can be made between "ritual online" (religious texts, etc., that are found online but the ritual itself

\footnotetext{
${ }_{75}^{74}$ Boellstorff, Coming of Age in Second Life, 185-87.

${ }^{75}$ Three works are of particular interest for exploring religion online further, outside the context of SL. First, see Lorne L. Dawson, "Religion and the Quest for Virtual Community," in Religion Online (New York: Routledge, 2004). Two books by Heidi Campbell are also helpful. See Heidi Campbell, Exploring Religious Community Online: We Are One in the Network (New York: Peter Lang, 2005). Her more recent book carries the exploration further: Heidi Campbell, When Religion Meets New Media, 1st ed. (New York: Routledge, 2010). Also, one of the earliest Christian communities online was called the "Church of Fools." Jenkins provides a unique perspective as a participant from early on: Simon Jenkins, "Rituals and Pixels: Experiments in Online Church." Online-Heidelberg Journal of Religions on the Internet 3, no. 1 (2008). Also, Kluver and Chen explore the nature of the spiritual world created by the Church of Fools: Randolph Kluver and Yanli Chen, "The Church of Fools: Virtual Ritual and Material Faith." Online-Heidelberg Journal of Religions on the Internet 3, no. 1 (2008).

${ }^{76}$ Technology in general has become an increasingly religious concern. As George Pattison notes, "technology has become a field of ultimate and thus of religious concern: to know or not to know in the manner promoted by technology, to be or not to be the being that technology is making of us: this is now a real and urgent question for thinking as well as for political, economic, and environmental policy-making." See George Pattison, Thinking about God in an Age of Technology (New York: Oxford University Press, 2005), 4.

${ }^{77}$ The presence of these centers and objects, as well as people participating as religious leaders has led some to explore issues of "technoshamanism" and "cybershamanism," which has led to some changes in ritual. For more on
} 
takes place offline) and "online ritual" (in which the ritual practice itself occurs in some sort of online space). ${ }^{78}$ Some scholars predict that as virtual worlds become more prominent, the difference between "real-world ritual" and "virtual-world ritual" will disappear. ${ }^{79}$ The virtual world promotes a great degree of flexibility, and religious practice in-world must be described on the basis of "clusters" to honor this difficulty to define strict boundaries. ${ }^{80}$ Some of this flexibility is likely due to a "filtering" effect, since people may be more comfortable having their avatar participate in a wider range of religious experiences than they would feel comfortable doing in real life. ${ }^{81}$

In the Jewish cluster, various synagogues can be found with Jewish rituals being conducted on different levels. There is a model of the Jerusalem Temple as well as an active synagogue called “Temple Beit Israel," which serves as a place for worship and religious education. ${ }^{82}$ The Christian cluster includes churches such as Ruach Ministry, which offers worship, prayer, and groups for religious discussion in SL (more on Christianity below). ${ }^{83}$ There is a large Muslim presence as well, with virtual mosques and even a reconstruction of Mecca. ${ }^{84}$ Buddhism and Hinduism are also present, with buildings and objects suited for religious ritual, such as candles, objects for meditation, and even special mats. ${ }^{85}$ Some of these spaces and

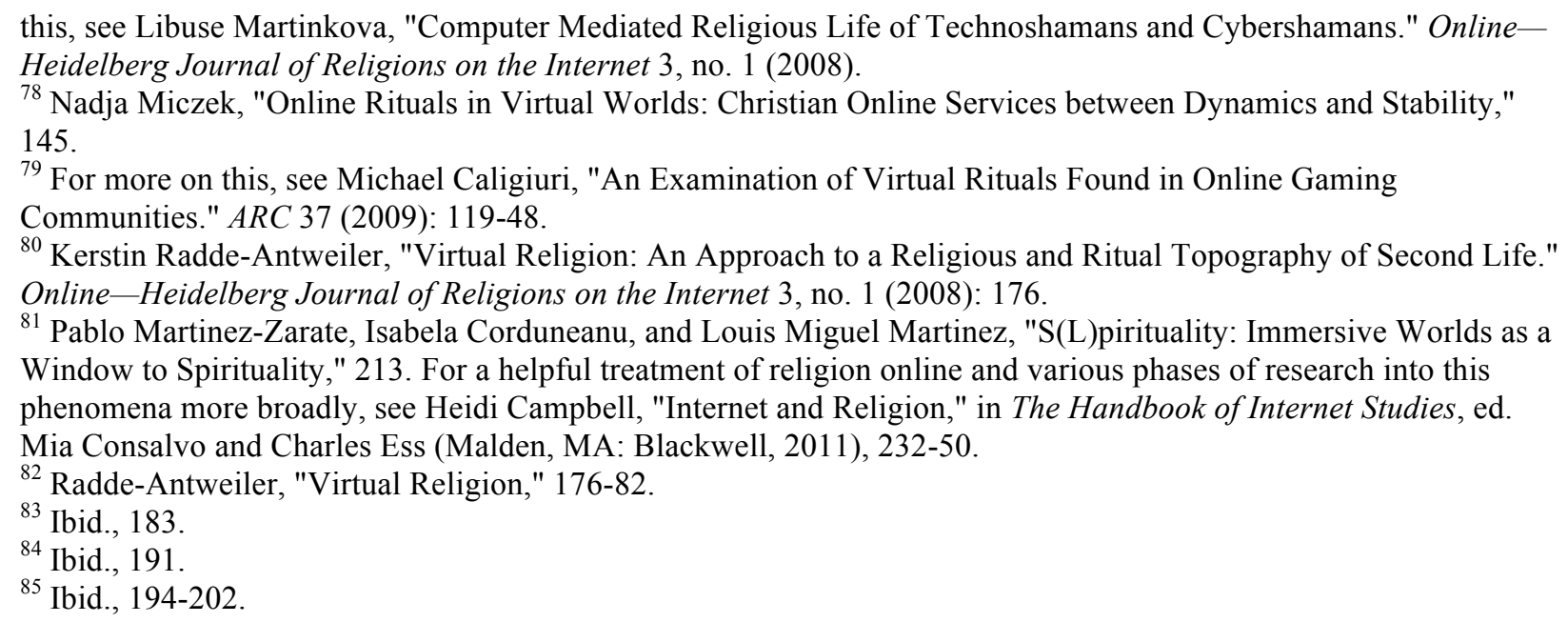


objects are constructed by people who participate in actual religious communities in real life, while others are built for general interest.

Christianity is present in SL in various ways. First, Christian worship occurs within SL, just like the other religions mentioned above. For some people, the issue of acceptance prevents them from participating in real-world worship. ${ }^{86}$ Second, some users essentially pray online through their avatar. "Some worship centers have animated poses for pray[er] and worship to assist avatars in kneeling, or raising their arms in praise." ${ }^{87}$ Third, Christians evangelize within virtual worlds as well. ${ }^{88}$ Fourth, Christian discipleship takes place as virtual churches host Bible studies and help people with real-world problems. ${ }^{89} \mathrm{SL}$ residents have found ways to mirror almost everything that happens in real-life Christianity, but with greater degrees of acceptance and control within the virtual community.

A description of SL that neglects to offer some thought on future concerns is incomplete. At this point, it is important to discuss two elements of the future of these worlds: the desire for "etopias" and the impact of SL activity on "real life."

The communities available in SL and other similar virtual worlds lead some to opine on the promise of future electronic utopias, or "etopias." There are two ways to think about this concept. First, etopias can be seen as experimental proving grounds for innovation in the real world. ${ }^{90}$ In his extensive work on virtual worlds, economist Castronova has argued that these worlds not only offer proving grounds, but they also will force the real world to change if it

\footnotetext{
${ }^{86}$ For example, one man came to LifeChurch as a cheetah wearing shorts, stating that he only feels accepted at this church, where he can be whatever he wants to be. See Johnson, Second Life, 247.

${ }^{87}$ Ibid., 249.

${ }^{88}$ One pastor of LifeChurch.tv says, "When Jesus told us to go into the world, we took him very literally." See ibid., 247.

${ }^{89}$ For example, Johnson speaks of a ministry called "Hope Springs Eternal," where Sher Salmson counsels residents about real or Second Life problems. Ibid., 249-54.

${ }^{90}$ Bainbridge says, "electronic utopias that have the potential to be the proving grounds for real-world social innovation and are already meeting places for real-world subcultures and social movements." See Bainbridge, Online Multiplayer Games, 89.
} 
wants to retain its residents, whom Castronova believes will choose virtual living over real living in greater numbers in the coming years. ${ }^{91}$ Even though Castronova's predictions of a massexodus to virtual worlds have failed to materialize to the degree he thought they would, these virtual worlds provide tools and motives for improving the real world.

Second, these etopias can be seen as "schizophrenic utopias" that allow people to develop plural identities. ${ }^{92}$ These communities and visions spring from the depth of experience available in virtual communities; "Friendships in Second Life were not always seen as poor approximations of their actual-world analogues: their intensity reveals that it is incorrect to assume that virtual worlds produce only 'loose' social ties. Many residents insisted that they had built friendships in Second Life that were as real as their friendships in the actual world." ${ }^{93}$ In fact, "Second Life ... sells the American Dream to those struggling to find utopia in real life."94 In this version of etopias, the better experience is found only online, and it leads to more and more people choosing to spend more and more time online in order to control their lives in a way that they cannot in the real world.

The concept of etopias quickly crosses over into discussion about the impact of SL on real life. Here, however, I am more interested in discussing behavioral "overflow" as activities within the virtual world spill over into the real world, since a dichotomy between who a person is in the virtual world and the real world can be unhelpful. "O5 "Overflow" occurs in two ways: actual behaviors in the real world, and a reconception of what reality actually is because of virtual world experience. The virtual experience is very involved; “The player must learn to act and

\footnotetext{
${ }^{91}$ See especially part three in Castronova, Exodus to the Virtual World.

${ }^{92}$ Hillis deals with this prospect extensively. See Ken Hillis, Digital Sensations: Space, Identity, and Embodiment in Virtual Reality (Minneaplis: University of Minnesota Press, 1999), 178-89.

${ }^{93}$ Boellstorff, Coming of Age in Second Life, 159.

${ }^{94}$ Johnson, Second Life, 41.

${ }^{95}$ See Mark J. P. Wolf, "From Simulation to Emulation: Ethics, Worldviews, and Video Games," in Virtual Morality: Morals, Ethics, and New Media, ed. Mark J. P. Wolf (New York: Peter Lang, 2003), 73.
} 
think a certain way in order to master a game. Player activity, then, is one way video games exert an influence; the player is performing actions, not merely watching someone else perform them, and over a long time, new skills and reflexes are learned." ${ }^{96}$ These new skills and resources shape the way people behave in real life. This includes not only violence, but also positive aspects of sociability. In fact, some psychologists tout the usefulness of virtual experiences for helping people work on identity issues and develop stronger character traits. ${ }^{97}$

Experience in the virtual world also changes the way people view reality. Investing time and energy in these worlds requires adapting ways of thinking and conceiving of the world. ${ }^{98}$ Virtual worlds alter the way that people conceive of their real-world relationships. Close relationships forged in virtual worlds, including some "family" relationships, change the user: "No longer is their world solely defined by their immediate RL families, friends and social circles, but they might begin to see how they fit in globally with others on a larger cultural continuum of expression." 99 Addiction to virtual relationships can lead to withdrawal from real relationships (which will be treated below). ${ }^{100}$ As SL and other virtual worlds become more and more common places for people to spend time, these future issues of etopias and behavioral spillover will only become more important, which is why analysis of ethical implications is necessary.

\section{Moral Formation Issues}

As a "secular liturgy," virtual worlds shape participants into lovers of certain things and ways of life. This raises ethical questions beyond simply what is a right or wrong action within

\footnotetext{
${ }^{96}$ Ibid., 64.

${ }^{97}$ For one example, see Marsha H. Levy-Warren, "Computer Games," in The Inner History of Devices, ed. Sherry Turkle (Cambridge, Mass.: The MIT Press, 2008), 77-85.

${ }^{98}$ Wolf, "From Simulation to Emulation," 71.

${ }^{99}$ Johnson, Second Life, 241.

${ }^{100}$ Boellstorff, Coming of Age in Second Life, 177.
} 
these worlds. Sherry Turkle has put the question well in her research into the subjective side of human-computer interaction: what kind of people are we becoming? ${ }^{101}$ Obviously, there is debate that could occur on what is right or wrong to do in-world; for example, is it a sin to kill my neighbor's avatar? Or, is it wrong to marry another avatar if I am married in real life? However, this section chooses to focus less on questions of ethics in-world and more on questions of the effects of in-world actions on real-life character development and community. Second Life will be analyzed not from the perspective of virtue in-world, but from the perspective of what sort of "secular liturgy" SL turns out to be, especially with the insights from Conyers in view. Though the information here could be structured in any number of profitable ways, the following uses the previous theological insights as a guiding template for analysis, thus the focus on vocation, attention, and community.

Perhaps one of the most dangerous ethical issues raised is that of control, which asserts self-will over against the concept of vocation in a theological sense. It seems rather harmless to have complete control over one's avatar's appearance and experience, but the danger lies in its seeming innocuousness. Games certainly provide a sense of control, ${ }^{102}$ and in a way they allow users to "play God." 103 Some feeling of control does occur in normal life and in a healthy way in human community, such as the control that comes from learning to play a musical instrument. However, virtual worlds offer a sense of control that requires little mastery of some sort of craft. ${ }^{104}$ There is one exception: some users develop a great degree of skill in designing avatars and building objects, which does correlate in some ways with traditional understandings of "craft." But this "control" that is gained by mastery of design and building can be distinguished

\footnotetext{
${ }^{101}$ Turkle, Second Self, 13.

102 Ibid., 72.

${ }^{103}$ Herzfeld, "Bodies Matter," 231.

${ }^{104}$ Jeffrey P. Zaleski, The Soul of Cyberspace: How New Technology Is Changing Our Spiritual Lives (San Francisco: HarperEdge, 1997), 188.
} 
from the general sense of control and sovereignty over the appearance and experience of one's avatar. The first is control over certain processes, while the second is more parallel to the idea of "playing God."

Time spent exercising this sort of control can serve to form the affections in an unhealthy way. This is likely related to each individual and the particular struggles and desires she brings to SL. So, while a person who has learned to live life without having to feel like she is in control all of the time may be able to participate in virtual worlds without having her affections shaped negatively, the exercise of complete control can be harmful to someone who already struggles with a feeling of a lack of control in his life. Seeking complete control through the virtual world can cause people either to seek more control over others in the real world or to flee the unpredictability of real life for more time in a controllable, virtual environment. For instance, a person who is able to control almost everything in their virtual world may struggle to deal with realities of community life, such as submitting to authority or enduring suffering. Conyers's warning about the problem with power and control for forming authentic human communities comes into play here, because these virtual experiences can cause harm in the way they form people to participate in real-world communities.

Noreen Herzfeld, in an essay on the impact of technology on our views of the body, notes, "virtue ethics warns us that one's character is formed by one's habits." ${ }^{105}$ Virtual worlds yield many opportunities to develop virtue or vice, but especially in light of the insight of Conyers, it is important to ask the question of attention. To the degree that virtual worlds serve as distraction from the real world, from real responsibilities, and from real relationships, they serve to take away from the skill of attention that is necessary for developing relationships in community and for prayer. For example, the constant stimulation available in a virtual world can

${ }^{105}$ Herzfeld, "Bodies Matter," 231. 
shape a person in such a way that they are not as skilled at things like listening attentively to other people in community. This does not mean that spending time in a virtual environment necessarily leads to distraction, and it does not mean that online relationships cannot be "real" and beneficial. Some users might enter religious portions of SL regularly in order to exercise a habit of prayer with their avatar, and others might develop great patience and empathy interacting with online friends. While such actions could contribute to cultivating attention, the general appeal of the virtual world is more of one toward distraction: get away from "First Life" in order to have a better second one. It is this posture of distraction that is problematic for developing attention, and the structure of virtual worlds tends to encourage this posture. Though exceptions certainly exist, distraction is a danger that must be raised and, surely, addressed.

Virtual communities, even admitting their diversity, ${ }^{106}$ seem to have little in common with the robust communities discussed by Conyers, and they perhaps fall into the critique of taking the form of communities but denying the substance of them. ${ }^{107}$ There are three particular angles that merit mention here. First, issues of suffering and alienation should drive people into life in community. Instead, virtual worlds invite people to escape: "Digital technology seems to be increasingly considered the means par excellence to liberate the self from material suffering and imperfection and to overcome the alienation of modern life." ${ }^{108}$ A strong concept of vocation refuses to flee the real world, even with its challenges and suffering, for another; instead, vocation requires hearing and faithfully responding.

\footnotetext{
${ }^{106}$ For a helpful treatment of the subject of community in Internet studies, see Lori Kendall, "Community and the Internet," in The Handbook of Internet Studies, ed. Mia Consalvo and Charles Ess (Malden, MA: Blackwell, 2011), $309-25$.

${ }^{107}$ Here it must be emphasized that we are using Conyers as our benchmark, not secular studies on community that argue about its definition and whether online communities meet their definition.

${ }^{108}$ Stef Aupers and Dick Houtman, "'Reality Sucks': On Alienation and Cybergnosis." Concilium, no. 1 (2005): 87. 
Second, virtual worlds offer a specter of relationship but, when abused, can harm real relationships: "Friendships and relationships were the source of addiction and the thing most harmed by that addiction." 109 Further, "Technology increasingly eliminates direct human interdependence. While our devices gives us greater personal autonomy, at the same time they disrupt the familiar networks of direct association." ${ }^{110}$ So while virtual worlds can seem to offer relationships and relief from suffering and alienation, they often circumvent genuine human community in doing so.

Not all online relationships, however, are abused, and evidence does suggest that online relationships can strengthen offline bonds. Based on study of the strength of online and offline networks, some argue "that virtual connectivity extends existing networks, strengthening offline bonds rather than replacing them. Certainly in socially slanted spaces, where interactions meet repeatedly over months and years, research suggests that online social systems form, through which information diffuses." 111 Evidence suggests that the problem is not online relationships per se, but addiction to these relationships. Also, there are plenty of examples of people playing online games with people they already know in real life, and this can potentially be positive, again depending on use. ${ }^{112}$ This angle on virtual and real-world communities, then, is more of a warning against addiction and abuse than against online relationships in themselves.

Third, some use virtual community as a substitute for real-world communities. Recalling Conyers's definition of community, it is questionable whether these online "communities" can really count in his view: "Here is a literal picture of the community that is in any real sense men

\footnotetext{
${ }^{109}$ Boellstorff, Coming of Age in Second Life, 178.

${ }^{110}$ Michael Heim, The Metaphysics of Virtual Reality (New York: Oxford University Press, 1993), 100.

${ }^{111}$ Aleksandra K. Krotoski, Evanthia Lyons, and Julie Barnett, "The Sociel Life of Second Life: An Analysis of the Social Networks of a Virtual World," in Living Virtually: Researching New Worlds, ed. Don Heider (New York: Peter Lang, 2009), 50.

${ }^{112}$ For example, see Jeffrey G. Snodgrass et al., "Enhancing One Life Rather than Living Two: Playing MMOs with Offline Friends." Computers in Human Behavior 27 (2011): 1211-22.
} 
and women communing together about life: nourished and informed by virtue of their rootedness, oriented toward their destiny, and open in love toward one another - this is the succinct meaning of community, the aim of which is to provide space and give nourishment to the human spirit." 113 While online communities are admittedly diverse, it does seem that few examples come to mind that match Conyers's definition. Online communities lack a rootedness, are oriented not toward a calling but toward a future constructed by force of the will, and are open in love only to others to whom the individual wants to be open.

The relationship between virtual communities and real-world communities is complicated. In fact, it seems that in many cases the "active get more active," because "people who use the Internet for civic purposes tended to become more actively involved in their community, while those who used the Internet heavily but for other purposes remained relatively disconnected from community activities." ${ }^{, 14}$ While this research did not focus on virtual worlds specifically, it does demonstrate that the outcome for real-world communities will differ depending on how particular people use and interact in online communities.

Virtual communities need not necessarily become substitutes for real-world communities. Again, it is a matter of abuse to be avoided. Recent research on communities and online relationships indicates that it is not a zero-sum game. In his monograph on presence and copresence in virtual environments, Ralph Schroeder argues:

The debates about our mediated relationships with others that have arisen with "new media" are quite revealing ... Recently, for example, the debate has been about whether the Internet contributes to fewer offline relationships and the like (Baym, 2002). Most

\footnotetext{
${ }^{113}$ Conyers, Listening Heart, 113.

${ }^{114}$ Maria Bakardjieva, "The Internet in Everyday Life: Exploring the Tenets and Contributions of Diverse Approaches," in The Handbook of Internet Studies, ed. Mia Consalvo and Charles Ess (Malden, MA: Blackwell, 2011), 67-68.
} 
findings, however, suggest that spending time in mediated relationships, including recently in relation to online games, for example, does not detract from spending time together or decrease the level of engagement in relationships "offline" (see, for example, Williams 2006). If we think in terms of "being there together," these debates can be put in a different perspective: It is not that purely mediated interpersonal relations should be seen as causing loneliness or being inferior to face-to-face relations and the like; rather, different media provide different possibilities for being there together in the changing landscape of interpersonal copresence. Face-to-face relationships and mediated relationships or time spent in mediated spaces should thus not be seen as a zero-sum game, despite the obvious fact that the amount of time spent in mediated relations and spaces has increased if seen in a longer-term historical perspective. ${ }^{115}$

The idea here is that virtual worlds and the communities that they afford do not necessarily take away from offline communities and relationships. This takes a holistic view of community and relationships: all types are held on equal footing as relationships, with no priority given to faceto-face, physical friends or communities.

Judgment on this issue of the relationship between online and offline relationships and communities pivots on how mediated relationships are evaluated. For someone like Conyers, the very idea of community entails physical presence to one another and to a physical place. For someone like Schroeder, these physical elements are less importance than the sense of "being there together," wherever "there" might "be." So, while much current research emphasizes the diversity of online community and potential benefits of this type of relationship, the insight from Conyers would caution against such a non-physical, non-place-oriented notion of community.

${ }^{115}$ Schroeder, Being There Together, 287-88. 
For Schroeder, it is a question of different types of community. For Conyers, it is a question of true community or no community at all.

Finally, participation in virtual worlds raises the issue of family life, one of the most basic forms of community. This comes out in three ways. First and most clearly, real-world responsibilities are often forsaken for the opportunity to spend more time in-world. Second, relationships in-world can alter real-world family relationships. Virtual environments are often filled with what is called "kin play," in which different people adopt familial roles in relation to other avatars (for example, my avatar could be the child and your avatar the mother). This can loop back and negatively influence relationships with future generations of real family members. ${ }^{116}$ It could also be positive: perhaps compassion and patience learned in a virtual world could yield more of those traits with real family members. However, when virtual worlds offer the opportunity to "trade in" family responsibilities for other activities and even other family members, who are easier to control and interact with because they do not make the same demands as real-life family members, it can form people to avoid others. Third, virtual worlds are one part of how the computer and the Internet are changing the shape of family life. "Living rooms have long been places of leisure, but now they contain an object from the office. Living rooms have also been places for shared activities — eating, watching television, talking — but now they contain something that monopolizes one person's attention and excludes the others."117

Seeking ethical norms can be a complex task, especially when dealing with something as nuanced as virtual worlds. Lines are blurred. In the real world, it is easier to make norms such as "do not murder," "do not steal," and "give to the poor." But in a virtual world, is it wrong to kill another character if that is the object of the game? What about stealing from others, if it is again

\footnotetext{
${ }^{116}$ Boellstorff, Coming of Age in Second Life, 175.

${ }^{117}$ Sonia Livingstone, "Internet, Children, and Youth," in The Handbook of Internet Studies, ed. Mia Consalvo and Charles Ess (Malden, MA: Blackwell, 2011), 351.
} 
within the rules of the game? And who are the poor in a virtual world that requires a certain degree of wealth for entry? The complexity of the virtual world and its relationship to the real world make such norms difficult to advocate.

Virtual worlds are not the first cause of any of the issues that serve to form moral agents. The fact is, people bring themselves to the virtual worlds, and it is their latent traits, whether good or bad, that can be intensified in a virtual environment. Newer research on the Internet's effects on social involvement, for example, has been called a "rich get richer" model, because those Internet users "who were extroverts and had stronger social support networks enjoyed positive social effects of Internet use, while the introverts and the isolated suffered some degree of decline in social involvement and psychological well-being." ${ }^{118}$ So the issue is not simply "virtual worlds make people do good/bad," but "virtual worlds provide unique opportunities and temptations that must be considered." Any norm must avoid absolutizing but instead focus on thoughtful engagement.

One potential complex of norms would be: "Situate virtual life within the greater context of the whole human life, prioritize community, character, and virtue in the real world, and take virtual reality seriously as a secular liturgy forming desire." The key elements are as follows. First, any ethical approach to virtual worlds must be situated in the context of the human flourishing with all of life in view, not just isolated portions. Second, the "real world" should be prioritized, because any semblance of community in the virtual world may indeed contain genuine goods, but those goods will likely emerge when the virtual community most closely resembles a real-world community. Third, virtual worlds form love and desire that then operates in the real world as agents choose and pursue goals. This cannot be ignored. However, discerning

\footnotetext{
${ }^{118}$ Bakardjieva, "The Internet in Everyday Life: Exploring the Tenets and Contributions of Diverse Approaches," 66. 
one or even a set of robust norms for something as complex as participation in virtual worlds can prove difficult.

A promising way forward can be found in looking for certain "postures." By "posture" I mean certain desires, tendencies, and moral vision. Since the theological perspective articulated above focused so carefully on issues of formation, in this section the emphasis will be on how virtual worlds such as Second Life can shape the loves and desires of moral agents, and thus effect the type of people they become. Three postures will be expounded in connection to Conyers, though more could be added.

The "God games" element of virtual reality can have a negative effect on forming people who hear and obey the call of God, even in the face of challenge and hardship. In the virtual world, users become accustomed to a great degree of control. This runs into the warnings mentioned by Conyers's critique of modernity, in which the desire for control reshapes relationships with others and with the wider world. Even if one does choose to participate in virtual reality, it is important to be aware of the allure of control. In the virtual world control can be enjoyed, but it can make people more controlling in the real world and less able to be part of a community that seeks to follow an external call.

Conyers's arguments about the importance of attention in the face of potential distraction can serve to form a helpful posture toward virtual reality. This can be brought to bear in two ways. First, virtual worlds can distract people, preventing them from hearing and obeying God's call. As Conyers noted, the call of God is often to some degree against the will of the one called, and one of the challenges is to resist distraction. Virtual worlds offer the opportunity to abandon the real world for hours at a time, including responsibilities and challenges that may be part of one's calling. Second, people are formed by those things to which they do pay attention. Some 
could argue that virtual worlds are a focal point for a great deal of attention, as people spend hours perfecting their avatars, their friendships, and their environment. However, this attention can have negative consequences on moral formation. It emphasizes a focus on projecting a desired self into an environment.

Christians must grapple with the immersive nature of virtual worlds and their attraction to a growing number of people. One important posture in response to virtual worlds is one of robust counter-formation. This connects clearly to Smith's descriptions of secular liturgies, and practical virtual reality, including but extending beyond Second Life, serve as influential, formative liturgies. Christian communities must acknowledge this, seek to understand what message is being conveyed, and work to provide a counter narrative and counter formation in order to form faithful Christians and strong communities.

\section{Conclusions and Further Research}

Virtual worlds are growing phenomena, and they demand theological engagement since they carry within them a certain anthropology. They shape people in important ways. They clearly constitute a type of "secular liturgy" that forms worshippers of a certain sort, as James K. A. Smith's work highlights. Some aspects that can be particularly consequential for developing strong life in community are the issues of attention, control, and vocation, themes brought out in A. J. Conyers's critique of modernity. Christian theology provides one possible perspective from which to address key issues brought up by virtual worlds, not rejecting them in toto, but evaluating them based on a robust understanding of moral formation, the centrality of character development, and the importance of strong communities.

Virtual worlds invite extensive additional research. This paper viewed virtual worlds primarily through the lenses provided by work by Smith and Conyers. The following four areas, 
at least, merit addressing. First, the issue of embodiedness and virtual reality needs more treatment. Some scholars see a dangerous anti-body tendency in advanced technology such as virtual reality, since these technologies can reduce the human to a disembodied mind or the sum of information in such a mind. ${ }^{119}$ Others argue that virtual worlds include a strong sense of embodied presence and thus are not subject to such criticisms. ${ }^{120}$ More work needs to be done to define embodiment and understand whether or not some framing of it can counter the accusation of the disembodied nature of virtual worlds.

Second, sexuality in virtual worlds will require theological analysis as more Christians spend time online. ${ }^{121}$ This issue is tied to the understanding of embodiment in virtual worlds. New norms are necessary for the nuances of virtual sexuality and its connections to real-world relationships.

Third, the issue of religious expression in-world invites further study. On the one hand, the flexibility of religious expression in virtual worlds points to a tendency toward syncretism. Whether such practices should be viewed as harmless exploration, spiritually dangerous, or something in between requires careful study and argument. On the other hand, the influence of religious participation in virtual worlds will continue to influence religious participation in the real world, with some people choosing the virtual in place of the real, and others expecting change in the real based on positive experiences that they have in the virtual.

Fourth, education (religious or otherwise) within virtual worlds provides a fruitful avenue for research. As more institutions seek to utilize Internet technology as much as possible,

\footnotetext{
${ }^{119}$ Herzfeld, "Bodies Matter," 226.

${ }^{120}$ Boellstorff, Coming of Age in Second Life, 134. For more on this, see Beatrice Bittarello, "Another Time, Another Space: Virtual Worlds, Myths and Imagination." Online-Heidelberg Journal of Religions on the Internet 3, no. 1 (2008): 246-66.

${ }^{121}$ For a more thorough overview of sexual practices within Second Life in particular, see Boellstorff, Coming of Age in Second Life, 160-65.
} 
presence in virtual worlds such as Second Life has become more common. Universities involved in learning activities in SL include Princeton, Harvard, Duke, Cambridge, and Oxford. ${ }^{122}$ Learning and teaching in worlds such as Second Life will become more common, and research is necessary to discern how best to do this and to evaluate potential losses in comparison to more traditional settings. ${ }^{123}$

\footnotetext{
${ }^{122}$ Johnson, Second Life, 17. For some challenges involved, see Charles Crook and Paul Light, "Virtual Society and the Cultural Practice of Study," in Virtual Society? Technology, Cyberbole, Reality, ed. Steve Woolgar (New York: Oxford University Press, 2002), 153-75.

${ }^{123}$ For more on this topic, see Judith Molka-Danielsen and Mats Deutschmann, Learning and Teaching in the Virtual World of Second Life (Trondheim: Tapir Academic Press, 2009).
} 